Division of Geological \& Geophysical Surveys

PUBLIC-DATA FILE 95-33a

\title{
GEOLOGIC MAP OF THE CHARLEY RIVER D-1, C-1, AND PART OF THE B-1 QUADRANGLES, EASTCENTRAL ALASKA
}

\author{
by \\ J.G. Clough, R.R. Reifenstuhl, C.G. Mull, D.S. Pinney, G.M. Laird, and S.A. Liss
}

October 1995

THIS REPORT HAS NOT BEEN REVIEWED FOR TECHNICAL CONTENT (EXCEPT AS NOTED IN TEXT) OR FOR CONFORMITY TO THE EDITORIAL STANDARDS OF DGGS.

\author{
Released by \\ STATEOFALASKA \\ DEPARTMENT OPNATURALRESOURCES \\ Division of Geological \& Geophysical Surveys \\ 794 University Avenue, Suite 200 \\ Fairbanks, Alaska 99709-3645
}




\title{
GEOLOGIC MAP OF THE CHARLEY RIVER D-1, C-1 AND \\ PART OF THE B-1 QUADRANGLES, EASTCENTRAL ALASKA
}

by

\author{
James G. Clough, Rocky R. ReifenstuhI, C. Gil Mull, DeAnne S. Pinney, \\ Gregory M. Laird, and Shirley A. Liss
}

\section{INTRODUCTION}

Geologic mapping of the Charley River D-1, C-1 and the northwest corner of the B-1 Quadrangles at 1:63,360 scale (sheets 1,2 and 3) took place June 13 to June 28, 1995. The study area adjoins 34 miles of the Yukon Territory, Canada border beginning approximately 50 miles north of the Yukon River between latitude $-65^{\circ} 30^{\prime} \mathrm{N}$ to latitude $66^{\circ} \mathrm{N}$ (fig. 1). The geology of the Step Mountain area, northwest corner of the Charley River B-1 Quadrangle was included in this study because of its well exposed stratigraphic sections. Geologic mapping was supplemented by interpretation of 1:63,360-scale falsecolor aerial photographs taken in 1982 and 1986 and 1:45,000-scale black and white aerial photographs taken in 1955.

Additional 1:63,360 scale geologic maps produced as part of this study include: (1) interpretive bedrock geologic maps (Clough and others, 1995); (2) surficial geologic maps (Pinney and others, 1995a); (3) derivative geologic-materials maps (Pinney and others, 1995b); and (4) geologic hazards maps (Pinney and others, 1995c).

The study area is unpopulated and roadless with access primarily by helicopter. Topography ranges from $1,000 \mathrm{ft}$ above sea level in river and stream valleys to $3,500 \mathrm{ft}$ elevations on mountain tops. Ridges below 2,200- to 3,000-ft elevations are heavily wooded with boreal forests dominated by black spruce. Outcrops are generally restricted to ridges and stream and river cuts. A traverse by boat down the Kandik River through the map area made accessed excellent river exposures.

\section{GEOLOGICAL SUMMARY}

The project area has 13 bedrock map units and 12 unconsolidated map units which range in age from lower(?) Paleozoic to Holocene. Complete map unit descriptions are provided on sheets 1 and 2 and are summarized below. Field station locations and traverses are shown on sheet 3 . The quadrangles studied are situated at the northern edge of the Kandik Basin / Charley River fold-and-thrust belt to the south (Brabb and Churkin, 1969; Dover and Miyaoka, 1988; Dover, 1992), and south of the Black River Quadrangle (1:63,360-scale map by Brabb, 1970), and the relatively less well known Porcupine platform (1:63,360-scale geologic map by Brosgé and others, 1966). 


\section{Previous Investigations}

The first geologic investigation in the region was in the Yukon-Alaska International boundary area between the Porcupine and Yukon Rivers (Maddren, 1912; Cairnes, 1914). Later geologic studies in the region (Mertie, 1930; 1933) established regional stratigraphic framework and structural elements. More recent stratigraphic studies were conducted by Churkin and Brabb (1965, 1967), Laudon and others (1966), Brabb (1969), and Lane and Ormiston (1976). Stratigraphic and structural studies in the adjacent Ogilvie River and Porcupine River quadrangles in the Yukon Territory include Norris $(1972,1976,1981$, 1982). Previous regional-scale bedrock geologic mapping includes 1:250,000-scale geologic maps by Brabb and Churkin (1969) and Dover and Miyaoka (1988) and a 1:100,000-scale geologic map by Dover (1992).

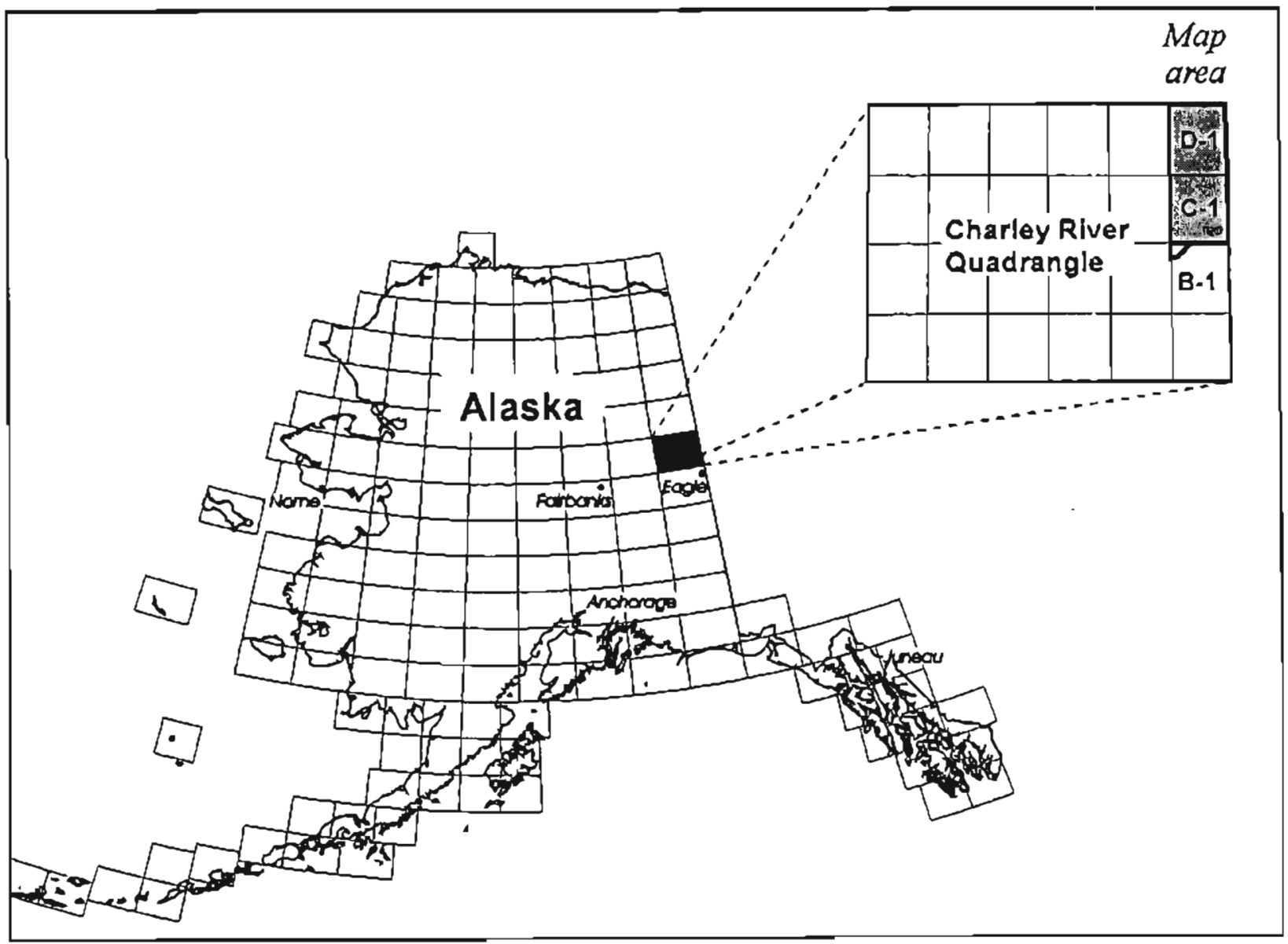

Figure 1. Location of map area in Charley River D-1, C-1 and B-1 Quadrangles. 


\section{Bedrock Geology}

Our bedrock micropaleontological age determinations were inconclusive and our map units are correlated with rocks exposed elsewhere in the Charley River Quadrangle and described in Brabb (1969), Brabb and Churkin (1969), Dover and Miyaoka (1988) and Dover (1992). Lower Cretaceous clastic rocks include the Kandik Group (Brabb and Churkin, 1969) comprised of (youngest to oldest): the Kathul Graywacke, Biederman Argillite, Indian Grave shale (informal name herein), and Keenan Quartzite (table 1). The Lower Cretaceous-age Kathul Graywacke has been subdivided herein into lower and upper informal units'. Our upper part of the Kathul Graywacke is mapped based on the amount of volcanic lithic content relative to the lower part. The upper Kathul Graywacke contains far less volcanic component (pyroxene, hornblende, plagioclase, and volcanic lithics) than the lower Kathul Graywacke. In the Charley River C-1 Quadrangle the informal name 'Indian Grave shale' has been assigned to a black- to light-gray-weathering shale and phylitic shale with pervasive cleavage which forms rubble on dip slopes two $\mathrm{km}$ northwest of Indian Grave Mountain. The close association of this unit with the underlying Keenan Quartzite is similar to the stratigraphic position of the Hauterivian to Barremian age 'pebble shale' unit above the Kemik Sandstone on Alaska's North Slope. The Glenn Shale (table 1) exposed in the southern part of the map

Table 1. Bedrock map units

\begin{tabular}{|c|c|c|c|}
\hline $\begin{array}{l}\text { MAP } \\
\text { UNIT }\end{array}$ & NAME or FORMATION & REFERENCES & AGE \\
\hline TKs & $\begin{array}{l}\text { poorly consolldated sandstone, } \\
\text { mudstone and conglomeratel } \\
\text { unnamed }\end{array}$ & Brabb and Churkin (1969) & Crelaceous and Tenliary \\
\hline Kkau & Kathul Graywacke-upper part & $\begin{array}{l}\text { Brabb (1969); subdivision } \\
\text { into lower and upper, this } \\
\text { paper }\end{array}$ & Lower Cretaceous (Albian?) \\
\hline Kkal & Kathul Graywacke-lower part & $\begin{array}{l}\text { Brabb (1969); subdivision } \\
\text { into lower and upper, this } \\
\text { paper }\end{array}$ & Lower Cretaceous (Albian?) \\
\hline $\mathrm{Kb}$ & Biederman Argillite & Brabb (1969) & Lower Cretaceous \\
\hline $\mathrm{Ks}$ & Indian Grave shale (informal) & this paper & Lower Cretaceous \\
\hline Kke & Keenan Quartzite & Brabb (1969) & $\begin{array}{c}\text { Lower Cretaceous } \\
\text { (Valanginian?) }\end{array}$ \\
\hline $\mathrm{KJg}$ & Glenn Shale & Brabb (1969) & $\begin{array}{c}\text { Jurassic(?) to Lower } \\
\text { Cretaceous }\end{array}$ \\
\hline $\mathrm{Pt}$ & Tahkandit Limestone & Brabb and Churkin (1969) & Permian (Guadalupian?) \\
\hline Ps & Step Conglomerate & Brabb (1969) & Permian (Guadalupian?) \\
\hline Dnr & Nation River Formation & Brabb and Churkin (1967) & Upper Devonian \\
\hline Dwv & Woodchopper(?) Volvanics & Brabb and Churkin (1969) & Lower Devonian \\
\hline $\mathrm{Pza}$ & phyllitic argillite & Brabb and Churkin (1969) & Paleozoic(?) \\
\hline Pzl & limestone and dolomite & $\begin{array}{l}\text { Brabb and Churkin (1969); } \\
\text { this paper }\end{array}$ & Paleozoic(?\}) \\
\hline
\end{tabular}


area (Charley River B-1 and C-1 Quadrangles) is Late Jurassic to Early Cretaceous in age (Dover and Miyaoka, 1988). These rocks were deposited in the northeastern edge of the Kandik Basin above the Permian-age Step Conglomerate, Tahkandit Limestone and the Upper Devonian-age Nation River Formation (table 1).

Porphyritic mafic volcanic rocks in the northwestern corner of the Charley River D-1 Quadrangle (sheet 1) are correlated with the Woodchopper Volcanics (Brabb and Churkin, 1969; Dover and Miyaoka, 1988) which are exposed on the Yukon River near the mouth of Woodchopper Creek, Charley River B-5 Quadrangle. Here, the rocks are interbedded with Lower Devonian limestone (Lane and Ormiston, 1976). Pending geochronological analysis we tentatively assign the Charley River D-1 volcanic rocks to the Woodchopper(?) Volcanics (table 1). Exposures of undifferentiated Paleozoic carbonate and argillite (table 1) are associated with the Woodchopper(?) Volcanics in the northern Charley River D-1 Quadrangle.

\section{Surficial Geology}

The region was not glaciated during Pleistocene time (Coulter and others, 1965) but was subjected to intense periglacial weathering when glaciers existed in nearby mountains and isolated uplands in eastern Beringia (Hopkins, 1967; Hopkins and others, 1982) Crests of bedrock ridges were stepped by cryoplanation processes during intense periglaciation, and ridge surfaces are littered with frost-shattered bedrock rubble and coarse, angular colluvium. Loess transported by winds blowing across nearby braided proglacial streams blankets most of the topography. This silt blanket has been locally eroded by fluvial processes and redeposited as thick organic-rich fills in valley bottoms (Péwé, 1975a,b). The region is underlain by discontinuous permafrost (Ferrians, 1965) Fine-grained valley fills are ice rich as indicated by the widespread distribution of open-

Tabie 2. Surficial map units

\begin{tabular}{|c|c|c|}
\hline $\begin{array}{c}\text { MAP } \\
\text { UNIT }\end{array}$ & NAME & AGE \\
\hline Qal & Alluvium & Holocene \\
\hline Qfp & Floadplain Alluvium & Holocene \\
\hline Qb & Point Bar Alluvium & Holocene \\
\hline Qat & Terrace Alluvium & Holocene \\
\hline Qaf & Alluvial Fan Deposits & Holocene \\
\hline Qc & Undifferentiated Colluvium & Holocene \\
\hline Qac & Undifferentiated Colluvium and & Holocene \\
& Alluvium & Holocene \\
\hline Qcl & Talus Deposits & Holocene \\
\hline Qca & Colluvial Apron Deposits & Holocene \\
\hline Qs & Undifferentiated Swamp Deposits & Holocene \\
\hline Ql & Undifferentiated Lacustrine Deposits & Late Pleistocene to Holocene \\
\hline Qel & Eolian Loess &
\end{tabular}


system pingos and thaw lakes in these deposits. Pingos commonly form in low lying exposures of heavily fractured bedrock, notably the Biederman Argillite which is dominated by pencil cleavage.

Two tephras(?) were identified in loess deposits. The age of one is unknown, but its shallow depth suggests it may be the Holcene White River Ash. The second tephra is older than 38,770 +5,540/-3,250 yr. B.P. (C-14 age date) and possibly correlative with the Old Crow Tephra (older than 70,000 yr. B.P.).

\section{Regional Structure}

The Charley River D-1, C-1 and B-1 Quadrangles are within the Charley River foldand-thrust belt (Dover, 1992). Geologic mapping indicates that folding and thrusting is the dominant structural style in all pre-Tertiary stratigraphy. All rock units are cut by high angle faults. Thrusting may be related to the fold-and-thrust beit of the northem Cordilleran in adjacent Yukon Territory. Many of the mapped faults are older-on-younger thrusts where stratigraphic control is known. Elsewhere the distribution of stsatigraphic units and facies relationships requires thrust fault juxtaposition. Thrusting direction, on the basis of map patterns, regional dips, and folds, is most commonly from northwest to southeast or from west to east. Tectonic transport is on the order of tens of kilometers, at a minimum. Age of thrusting is post-Albian age Kathul Graywacke deposition, and preMaestrichtian to Paleocene-age sedimentary rock unit deposition.

High angle faults also juxtapose rock units, are typically post thrusting, and trending northeasterly to northwesterly. The Tintina fault zone lies $50 \mathrm{~km}$ southwest of the map area. This major right-lateral system has produced over $450 \mathrm{~km}$ of pre-Late Cretaceous offset in Canada, and up to $50 \mathrm{~km}$ of post-Eocene offset. High angle faulting in the Charley River area may be, in part, splays related to Tintina fault movement.

\section{ACKNOWLEDGMENTS}

We wish to thank L. Katherine Queen and Peggy J. Young (University of Alaska Fairbanks student interns), and Gina R.C. Graham (Alaska Division of Geological and Geophysical Surveys (ADGGS)) for their prodigious effort in digital map production. The efforts of Thomas E. Smith (former State Geologist and ADGGS Director) and Milton A. Wiltse (ADGGS Acting Director) helped make this project possible.

This project is supported by the U.S. Geological Survey, Deparment of the Interior, under assistance Award No. 1434-94-A-1221. 


\section{REFERENCES}

Brabb, E.E., 1969, Six new Paleozoic and Mesozoic formations in east-central Alaska: U.S. Geological Survey Bulletin 1274-I, 26 p.

1970, Preliminary Geologic Map of the Black River Quadrangle, east central Alaska: U.S. Geological Survey Miscellaneous Geologic Investigations Map I-601, scale 1:250,000 map.

Brabb, E.E., and Churkin, M., Jr., 1969, Geologic map of the Charley River quadrangle, east-central Alaska: U.S. Geological Survey Miscellaneous Geologic Investigations Map I-573, scale 1:250,000 map.

Brosgé, W.P., Reiser, H.N., Dutro, J.T, and Churkin, M., 1966, Geologic Map and Stratigraphic Section, Porcupine River canyon, Alaska: U.S. Geological Survey Open-File Report 263, I:63,360.

Cairnes, D.C., 1914, The Yukon-Alaska international boundary, between Porcupine and Yukon Rivers: Canada Geological Survey Memoir 67, 161 p.

Churkin, M., Jr., and Brabb, E.E., 1965, Ordovician, Silurian, and Devonian biostratigraphy of east-central Alaska: American Association of Petroleum Geologists Bulletin, v. 49 , no. 2, p. 172-185.

1967, Devonian rocks of the Yukon-Porcupine Rivers area and their tectonic relations to other Devonian sequences in Alaska: $\underline{i}$ D.H. Oswald (ed.), International Symposium on the Devonian System, Alberta Society of Geologists, Calgary, Alberta, v. 2 , p. $227-258$.

Clough, J.G, Mull, C.G., Reifenstuhl, R.R, Liss, S.A., Laird, G.M., and Pinney, D.S., 1995, Interpretive bedrock geologic map of the Charley River D-1, C-1 and part of the B-1 Quadrangles, Eastcentral Alaska: Alaska Division of Geological and Geophysical Surveys Public-data File 95-33b, three sheets, 1:63,360-scale and 1:100,000-scale.

Coulter, H.W., Hopkins, D.M., Karlstrom, T.N.V., Péwé, T.L., Wahrhaftig, Clyde, and Williams, J.R., 1965, Map showing extent of glaciations in Alaska: U.S. Geological Survey Miscellaneous Geologic Investigations Map I-415, scale 1:2,500,000, 1 sheet.

Dover, J.H., 1990, Geology of east-central Alaska: U.S. Geological Survey Open-File Report 90-289, $66 \mathrm{p}$. 
1992, Geologic map and fold and thrust belt interpretation of the southeastern part of the Charley River Quadrangle, east-central Alaska: U.S. Geological Survey Miscellaneous Investigations Map I-1942, scale 1:100,000, 2 sheets.

Dover, J.H., and Miyaoka, R., 1988, Reinterpreted geologic map and fossil data, Charley River Quadrangle, east-central Alaska, U.S. Geological Survey Miscellaneous Field Studies Map 2004, scale 1:250,000, 2 sheets.

Ferrians, O.J., Jr., 1965, Permafrost map of Alaska: U.S. Geological Survey Miscellaneous Geologic Investigations Map I-445, scale 1:2,500,000, 1 sheet.

Hopkins, D.M., 1967, The Bering Land Bridge: Stanford, Stanford University Press, 495 p.

Hopkins, D.M., Matthews, J.V., Jr., Schweger, C.E., and Young, S.B., 1982, Paleoecology of Beringia: New York, Academic Press, 489 p.

Lane, HR, and Ormiston, A.R., 1976, The age of the Woodchopper Limestone (Lower Devonian), Alaska: Geologica et Palaeontologica, v. 10, p. 101-108.

Laudon, L.R, Hartwig, A.E. , Morgridge, D.L., and Ormenik, J.B., 1966, Middle and late Paleozoic Stratigraphy, Alaska-Yukon border area between Yukon and Porcupine Rivers: American Association of Petroleum Geologists Bulletin, v. 50, p. 1868-1889.

Maddren, A.G., 1912, Geologic investigations along the Canada-Alaska boundary: U.S. Geological Survey Bulletin 520-K, p. 297-314.

Mertie, J.H., Jr., 1930, Geology of the Eagle-Circle districh, Alaska: U.S. Geological Survey Bulletin 816, $168 \mathrm{p}$.

1933, The Tatonduk-Nation district: U.S, Geological Survey Bulletin 836-E, p. $347-443$.

Norris, D.K., 1972, En echelon folding in the northern Cordillera of Canada: Bulletin of Canadian Petroleum Geologists, v. 20, no. 3, p. 634642.

1976, The North American Cordillera in Canada north and east of the Tintina Fault: [abs.]: 25th International Geologic Congress, v. 3, p. 690-692.

1981, Porcupine River geology, Yukon Territory: Geological Survey of Canada Map 1522A, 1:250,000 scale, 1 sheet. 
1982, Ogilvie River geology, Yukon Territory: Geological Survey of Canada Map 1526A, 1:250,000 scale, I sheet.

Péwé, T.L., 1975a, Quaternary geology of Alaska: U.S. Geological Survey Professional Paper 835, $145 \mathrm{p}$.

1975b, Quaternary stratigraphic nomenclature in unglaciated central Alaska:

U.S. Geological Survey Professional Paper 862, 32 p.

Pinney, D.S., Clough, J.G., and Liss, S.A., 1995a, Surficial geologic map of the Charley

River D-1, C-1 and part of the B-1 Quadrangles, Eastcentral Alaska: Alaska Division of Geological and Geophysical Surveys Public-data File 95-33c, two sheets, $1: 63,360$-scale.

Pinney, D.S., Clough, J.G., Reifenstuhl, R.R., Mull, C.G., Liss, S.A., and Laird, G.M., 1995b, Derivative geologic-materials map of the Charley River D-1, C-1 and part of the B-1 Quadrangles, Eastcentral Alaska: Alaska Division of Geological and Geophysical Surveys Public-data File 95-33d, two sheets, 1:63,360-scale.

Pinney, D.S., Clough, J.G., Reifenstuhl, R.R., Mull, C.G., Liss, S.A., and Laird, G.M., 1995c, Geologic hazards map of the Charley River D-1, C-1 and part of the B-1 Quadrangles, Eastcentral Alaska: Alaska Division of Geological and Geophysical Surveys Public-data File 95-33e, two sheets, 1:63,360-scale. 